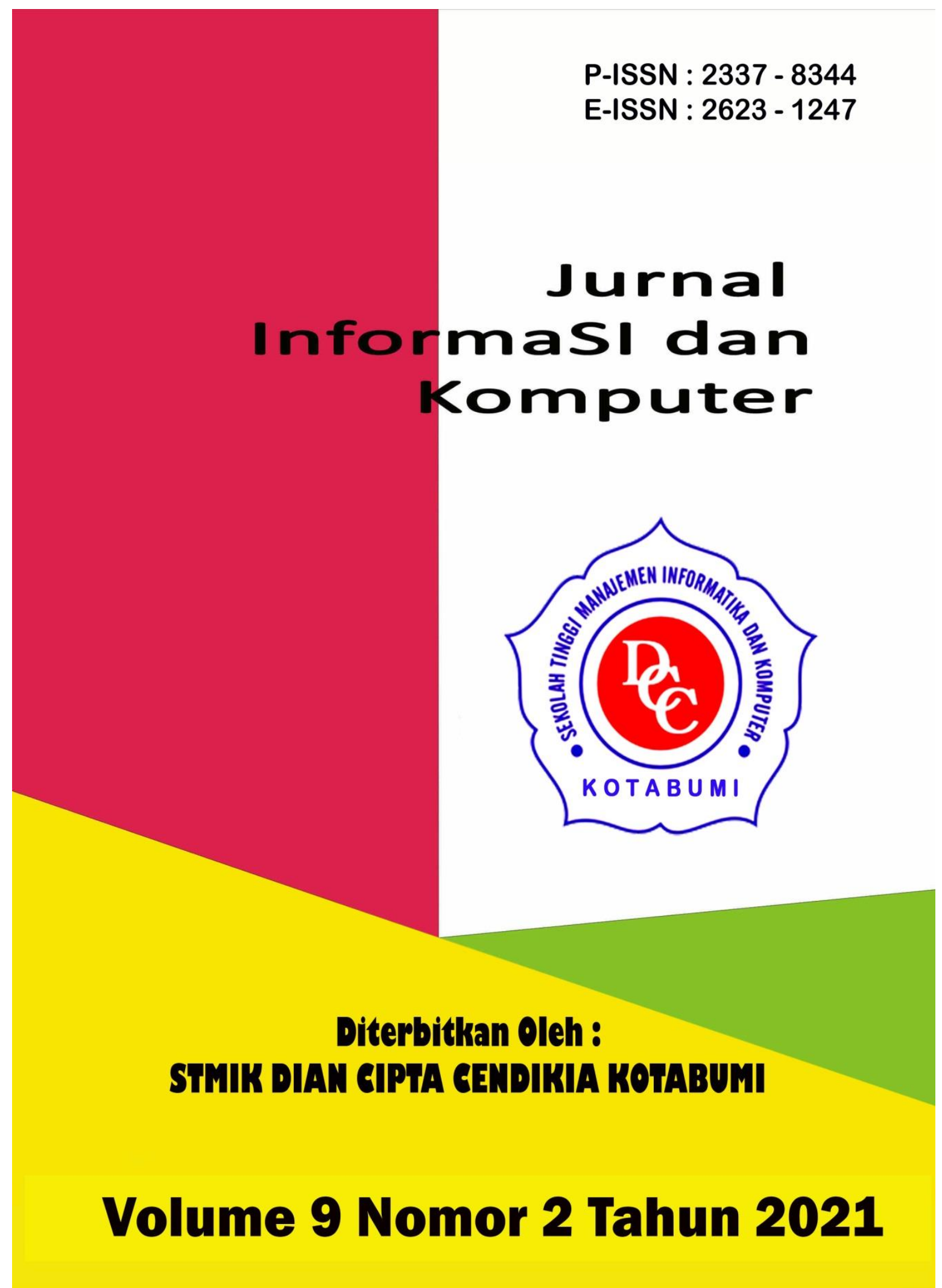




\section{Penerbit}

\section{Lembaga Penelitian STMIK Dian Cipta Cendikia Kotabumi}

Hak atas naskahh/tulisan tetap berada pada penulis, isi diluar tangung jawab penerbit dan Dewan Penyunting

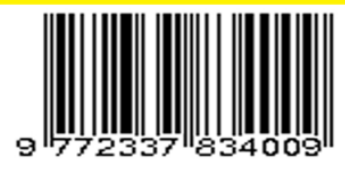




\section{PENGANTAR REDAKSI}

Puji syukur dipanjatkan kehadirat Tuhan Yang Maha Esa, atas karunia dan limpahan rahmatNYA jualah Jurnal Informasi dan komputer (JIK) STMIK Dian Cipta Cendikia Kotabumi ini dapat terwujud.Jurnal Informasi dan Komputer (JIK) yang terbit dua (2) kali dalam setahun ini merupakan suatu wadah untuk penyebar luasan hasil-hasil penelitian, studi pustaka, karya ilmiah yang berkaitan dengan Informasi dan Komputer khususnya bagi dosen-dosen STMIK Dian Cipta Cendikia Kotabumi serta umumnya para cendikiawan, praktisi, peneliti ilmu Informatika dan Komputer.

Harapan, dengan diterbitkannya Jurnal Informasi dan Komputer (JIK) ini sebagai salah satu bentuk sumbangan pemikiran dalam pengembangan ilmu informatika dan komputer yang berkaitan dengan kajian-kajian di bidang tekhnologi Informatik, Komunikasi Data dan Jaringan Komputer, perancangan dan Rekayasa Perangkat Lunak, serta ilmu-ilmu yang terkait dengan bidang Informasi dan Komputer lainnya.

Berkenaan dengan harapan tersebut, kepada para peneliti, dosen dan praktisi yang memiliki hasil-hasil penelitian, kajian pustaka, karya ilmiah dalam bidang tersebut diatas, dengan bangga redaksi Jurnal Informasi dan Komputer (JIK) menerima naskah ringkasan untuk dimuat pada jurnal Informasi dan Komputer (JIK) STMIK Dian Cipta Cendikia Kotabumi dengan berpedoman pada penulisan naskah jurnal sebagaimana dilampirkan pada halaman belakang (Bagian kulit dalam) buku jurnal ini.

Mutu dari suatu jurnal ilmiah tidak hanya ditentukan oleh para pengelolanya saja, tetapi para penulis dan pembaca jualah yang mempunyai peranan besar dalam meningkatkan mutu jurnal Informatika dan Komputer ini. Merujuk pada realita ini kamu sangat mengharapkan peran aktif dari peneliti untuk bersama-sama menjaga dan memelihara keberlangsungan dari jurnal Informasi dan Komputer STMIK Dian Cipta Cendikia Kotabumi ini. Yang juga tidak kalah pentingnya dari partisipasi tersebut diatas, adalah saran dan kritik yang membangun dari pembaca yang budiman agar kiranya dapat disampaikan langsung kepada redaksi JIK. Saran dan kritik yang membangun akan dijadikan masukan dan pertimbangan yang sangat berarti guna peningkatan mutu dan kualitas Jurnal Informasi dan Komputer STMIK Dian Cipta Cendikia Kotabumi.

Tak lupa diucapkan terima kasih yang tak terhingga atas perhatian dan kerjasama dari semua pihak yang tak dapat disebutkan satu persatu hingga dapat diterbitkan nya Jurnal Informasi dan Komputer (JIK) STMIK Dian Cipta Cendikia Kotabumi. Semoga apa yang telah diperbuat untuk kebaikan akan menjadi amal ibadah, amin.

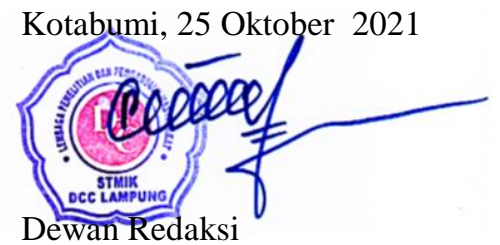




\section{JURNAL INFORMASI DAN KOMPUTER}

Volume 9 Nomor 2 Oktober 2021

Jurnal Informasi dan Komputer merupakan Sarana informasi ilmu pengetahuan, Tekhnologi dan Komunikasi yang berupa hasil penelitian, tulisan ilmiah, Ataupun studi pustaka. Jurnal ini terbit dua kali setahun pada bulan April dan Oktober. Berisi hasil penelitian ilmiah di bidang informatika yang bertujuan untuk menghubungkan adanya kesenjangan antar kemajuan teknologi dan hasil penelitian. Jurnal ini di terbitkan pertama kali pada tahun 2013.

Penanggung Jawab:

Ketua STMIK Dian Cipta Cendikia Kotabumi

\section{Pembina:}

Ketua STMIK Dian Cipta Cendikia Kotabumi Ketua Lembaga Penelitian STMIK Dian Cipta Cendikia Kotabumi

\section{Pimpinan Redaksi}

Dwi Marisa Efendi,.S.Kom.,M.Ti

\section{Redaksi pelaksana}

Rustam,.S.Kom,.M.Ti (STMIK Dian Cipta Cendikia Kotabumi)

Nurmayanti M.Kom (STMIK Dian Cipta Cendikia Kotabumi)

Sukatmi,.S.Kom., M.Kom (AMIK DCC Bandar Lampung)

Sampurna Dadi Riskiono,M.Kom (Universitas Teknokrat Indonesia)

Ifo Wahyu Pratama,S.Kom.,M.Ti(AMIK MASTER Lampung)

\section{Mitra Bestari}

Dr. RZ. ABDUL AZIZ, ST., MT (Institut Informatika dan Bisnis Darmajaya)

Dr. Dadang Sudrajat, S.Si, M.Kom (STMIK IKMI Cirebon)

Dr. Septafiansyah Dwi Putra, S.T., M.T (Politeknik Negeri Lampung)

Dr. Evi Grativiani, S.E., M.S.I (Universitas Sebelas Maret)

Rohmat Indra Borman ( Universitas Teknokrat Indonesia )

Ferry Wongso, S.KOm., M.Kom ( STMIK Darma Pala Riau)

Ferly Ardhy, S.Kom., M.Ti ( Universitas Aisyah Pringsewu )

Firmansyah, S.E., M.Si (STMIK Darma Pala Riau)
Amarudin (Universitas Teknokrat Indonesia)

Didi Susianto, S.T., M.Kom (AMIK Dian Cipta Cendika Bandar Lampung)

Alhibarsyah, St., M.Kom (STMIK Tunas

Bangsa Bandar Lampung)

Kemal Farouq Mauladi, S.Kom .M.Kom (Universitas Islam Lamongan)

Rima Mawarni, M.Kom ( STMIK Dian Cipta Cendikia Kotabumi)

Wira Jaya Hartono, S.Pd., M.Pd ( STMIK Darma Pala Riau)

Penerbit : STMIK Dian Cipta Cendikia Kotabumi Bekerja Sama Dengan LPPM STMIK Dian Cipta Cendikia Kotabumi.

\section{Alamat Redaksi/Penerbit:}

Jl. Negara No. 3 Candimas Kotabumi Lampung Utara

No Telpon/Fax 072423003

Email : 1ppm-stmik@dcc.ac.id 


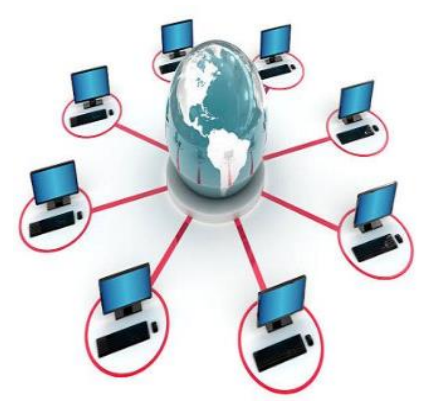

\section{JURNAL INFORMASI DAN KOMPUTER VOL. 9 NO. 2 THN. 2021}

\section{DAFTAR ISI}

Halaman

Sistem Informasi Akuntansi Persedian Barang Berbasis Web Pada Lembaga

Permasyarakatan Kelas II A Banceuy Bandung : "Kelompok Tani Desa Banjar Kertarahayu” Teuku Rian Hardiyansyah, Fatia Salsa Azzahra (Politeknik Piksi Ganesha Bandung ${ }^{1,2}$ )

Penerapan Finite State Automata Pada Vending Machine Penjual Obat Non Resep

Dokter Dan Keperluan Medis

Eko Supriyanto $^{1}$, Angga Ardiansyah ${ }^{2}$, Frieyadie $^{3}$, Sri Rahayu ${ }^{4}$, Windu Gata ${ }^{5}$

(Universitas Nusa Mandiri ${ }^{12}$ )

Sistem Pendukung Keputusan Untuk Menentukan Kelayakan Pengajuan Sertifikasi Guru Dengan Metode Simple Additive Weighting (Studi Kasus : Ma Al Muhajirin Janti Jogoroto Jombang)

Budiman, umam baharudin, winarti

(Universitas Darul 'Ulum Jombang)

Perancangan Infrastruktur Domain Name Server Lokal Menggunakan Ubuntu Server 16.04

Pada PT. Xyz

Zaenal Mutaqin Subekti, Hendra Setiawan, Satria, Widia Murni Wijaya,

Aliy Hafiz, Warsudi

(STMIK Bani Saleh, Universitas Negeri Yogyakarta, AMIK Dian Cipta Cendikia,

STMIK MIC CIkarang)

Perancangan Sistem Informasi Idea Proposal (Ip) Berbasis Web Pada Pt. Paxel Algorita Unggul

Julian Murhan Sahputra, Indah Purnamasari

(Universitas Nusa Mandiri ${ }^{12}$ )

Sistem Pendukung Keputusan Untuk Menentukan Ekstrakurikuler Atletik

Berdasarkan Bakat Siswa Menggunakan Metode Profile Matching

Agnes Basuki, Petrus Sokibi, Tiara Eka Putri

(Universitas Catur Insan Cendekia)

Penerapan Algoritma K-Means Untuk Pengelompokan Usia Calon Penerima Vaksin

Di Kab. Ngawi

Irna Yuniarfi, Saifulloh

(Universitas PGRI Madiun ${ }^{12}$ )

System Penilaian Seleksi Calon Karyawan Baru Menggunakan Metode Simple Additive Weighting (SAW) Di PT.TNA

Anik Sri Wahyuningsih, Yudhi Firmansyah

(Universitas Panca Sakti Bekasi ) 
Perancangan Sistem Informasi Pembayaran SPP Menggunakan Framework Laravel Ichwan Habib Moudi

(Universitas Panca Sakti Bekasi)

Implementasi Algoritma K-Means Dan Algoritma Apriori Optimasi Kinerja Ecu

(Study Kasus Mobil Avanza Dan Xenia)

Sigit Mintoro' Asep Afandi

(STMIK Dian Cipta Cendikia Kotabumi)

Sistem Pakar Penyakit Buah Kakao Untuk Peningkatan Hasil Panen Kakao Menggunakan

Metode Case Base Reasoning (CBR) Berbasis Web Mobile

Aliy hafiz, Verawati

(AMIK Dian Cipta Cendikia,Bandar Lampung)

Penerapan Metode Rapid Application Develomment (RAD) Dalam Pengembangan

Sistem Pemesanan Menu Berbasis Android

Aris Baihaqi, Tumini

(Fakultas Sains dan Teknologi ${ }^{1,2}$ )

Rancang Bangun Sistem Informasi Geografis Pariwisata Di Lampung Timur

Sukatmi, Rexa Alfa Rizi

(AMIK DCC Bandar Lampung ${ }^{12}$ )

Implementasi Psak No. 45 Pada Proses Penyusunan Laporan Keuangan Menggunakan

M.S. Excel Dan Aplikasi Accurate Accouting Pada STMIK Bani Saleh

Marhakim, Willy Adam

(STMIK Bani Saleh ${ }^{12}$ )

Sistem Prediksi Harga KOPI LAMBAR ( Lampung Barat) Dengan Metode

Backpropagation, dan Double Exponential ( Studi Kasus BUMDES )

Supriyanto, Dwi marisa Efendi,Rhomadhon

(STMIK Dian Cipta cendikia Kotabumi ${ }^{1-}$ )

Sistem Informasi Pemasaran Produk Umkm Berbasis Web Pada Kecamatan Bumi

Nabung Lampung Tengah

Yuli Syafitri, Agus Prasetyo, Reni Astika

(AMIK Dian Cipta Cendikia Bandar Lampung)

Rancang Bangun Aplikasi Pembelajaran Aksara Lampung Berbasis Android

Ferly Ardhy, Hendra Syahrobi

(Universitas Aisyah Pringewu ${ }^{1,}$ STMIK Dian Cipta Cendikia ${ }^{2}$ )

Sistem Pakar Diagnosa Penyakit Kulit Pada Balita Menggunakan Metode Naïve

Bayes Dan Forward Chaining Studi Kasus Puskesmas Cempaka Sungkai Selatan

Sidik Rahmatullah, Rima Mawarni

(STMIK Dian Cipta Cendikia Kotabumi ${ }^{12}$ )

Rekayasa Perangkat Lunak Perhitungan Harga Pokok Produksi Metode

Full Costing Pada Umkm Mitra Cake Di Bandar Lampung

Pitrawati, Arif Sanjaya

(AMIK Dian Cipta Cendikia, Bandar Lampung) 
Rancang Bangun Sistem Ujian Online Menggunakan Algoritma Cosine Similarity

Berbasis Web

Haryono, Zaenal Mutaqin Subekti, Widiyawati, Hidayatullah

(STMIK Bani Saleh ${ }^{1234}$ )

Model Aplikasi Helpdesk Ticketing System Berbasis Web Menggunakan Metode Rad

Indra Permana

Pattern Recognition Tulisan Tangan Huruf Hijaiyah Menggunakan Metode

Convolutional Neural Network (CNN)

Mufassiril Abror, Nopiyanto

(Universitas Panca Sakti Bekasi ${ }^{12}$ )

Aplikasi Sistem Informasi Keuangan Berbasis Android Di Perumahan Taman

Karang Bahagia

Melda Ayulestari

(Universitas Panca Sakti Bekasi)

Audit Pelayanan Sistem Rujukan Online Puskesmas Menggunakan Framework COBIT 5.0

Nurmayanti, Merri Parida, Ngajiyanto, Ina Anzalna

(STMIK Dian Cipta Cendikia Kotabumi ${ }^{1234}$ )

Perancangan Sistem Informasi Pengolahan Data Nilai Siswa Berbasis Web

Erin Ermawati, Anik Sri Wahyuningsih

(Fakultas Sain dan Teknologi, Universitas Panca Sakti Bekasi ${ }^{12}$ )

Pengembangan Sistem Pelaporan Data Hasil Inspeksi Barang Berbasis Web

Siska Putriani

(Universitas Pancasakti Bekasi)

Penerapan Extreme Programming Dalam Perancangan Aplikasi Web Food Market

Tumini, Hilman Septiana

(Fakultas Sains dan Teknologi Universitas Panca Sakti Bekasi ${ }^{1,2}$ )

Sistem Pencarian Barang Berbasis Website Menggunakan Php Dan Mysql

Studi Kasus PT. Surya Technology Industri Sulaeman

(Universitas Panca Sakti Bekasi)

Implementasi Metode Prototype Pada Sistem Peminjaman Alat Kerja Berbasis Web

Di PT SK Metalindo

Ali Mulyanto, Arjun Gunawan

(Univeritas Panca Sakti Bekasi)

Aplikasi Tata Cara Wudhu Menggunakan Teknologi Augmented Reality

Sebagai Media Pembelajaran Di TK Al Fatih

Ahmad Yakub , Idarul Fadli

(Universitas Panca Sakti Bekasi ${ }^{12}$ )

Sistem Pakar Diagnosa Penyakit Ayam Petelur Menggunakan Metode Certainty Factor

Berbasis Web Mochammad

Taufiq Hidayat, Ali Mulyanto

(Universitas Panca Sakti Bekasi ${ }^{12}$ ) 
Penerapan Metode Prototyping Dalam Perhitungan Hasil Produksi Menggunakan

Arduino Uno R3 Dan Php Di PT. Indonesia Epson Industry

Amandha Aulia, Ajar Rohmanu

(Universitas Panca Sakti Bekasi ${ }^{12}$ )

System Pendukung Keputusan Penentuan Guru Teladan Dengan Metode Profile Matching

Hasbulloh, Agmawarnida

(Universitas Panca Sakti Bekasi ${ }^{1,2}$ )

Implementasi Waterfall Method Pada Aplikasi Buku Induk Siswa Berbasis Web

Idam Holid, Yogie Krisnayadi

(Universitas Panca Sakti ${ }^{12}$ )

Pengembangan Text To Speech Media Pembelajaran Untuk Pengenalan

Anggota Tubuh Manusia Kelas V Sekolah Dasar

Juwanda Saputra, Ali Mulianto

(Teknik Infomratika Fakulutas Sains dan Teknologi ${ }^{12}$ )

Perancangan Sistem Peminjaman Barang Berupa Aset Tetap Berbasis Web

Pada Lembaga Permasyarakatan Kelas II A Banceuy Bandung

Guntur Salasa Priambodo, Perwito, Candra Mecca Sufyana

(Politeknik Piksi Ganesha Bandung ${ }^{1,2,3}$ )

Metode Pemilihan Karyawan Terbaik Sebagai Penentu Goodwill Perguruan Tinggi

Dengan Menggunakan Metode Topsis (Studi Kasus Perguruan Tinggi Di Lampung Utara)

Dwi Sartika, Pakarti Riswanto

(STMIK Dian Cipta Cendikia Kotabumi)

Sistem Pendukung Keputusan Pemilihan Merek Smartphone Menggunakan

Metode Analytical Hierarchy Process (AHP)

Ade Kiki Fatmawati, Muhammad Sultan Raflie, Norma Yunita

(Universitas Nusa Mandiri ${ }^{123}$ )

Pattern Recognition Aksara Lampung Menggunakan Algoritma Neural Network

Metode Analytical Hierarchy Process (AHP)

Nopiyanto, Rahmadi

(Universitas Panca Sakti Bekasi) 


\title{
REKAYASA PERANGKAT LUNAK PERHITUNGAN HARGA POKOK PRODUKSI METODE FULL COSTING PADA UMKM MITRA CAKE DI BANDAR LAMPUNG
}

\author{
Pitrawati $^{1}$, Arif Sanjaya ${ }^{2}$ \\ Komputerisasi Akuntansi ${ }^{1}$, Komputerisasi Akuntansi ${ }^{2}$ \\ AMIK Dian Cipta Cendikia, Bandar Lampung \\ Jl. Cut Nyak Dien No. 65 Durian Payung (Palapa) Bandar Lampung \\ E-mail : pitradcc@gmail.com, arifsanjaya23@gmail.com
}

\begin{abstract}
ABSTRAK
UMKM Mitra Cake adalah salah satu UMKM yang bergerak dibidang produksi Makanan kue di Bandar Lampung. Dalam proses perhitungan harga pokok produksi masih dilakukan dengan cara menghitung manual, sehingga ketepatan hitungan yang kurang akurat dan berakibat pada ketidaktepatan dalam perhitungan sisa hasil usaha, oleh karena itu Mitra Cake membutuhkan aplikasi yang mampu menghitung dan mengolah data harga pokok produksi yang tepat sehingga tidak salah dalam penentuan harga pokok produksi.

Tujuan penelitian ini untuk menghasilkan aplikasi perhitungan harga pokok produksi pada UMKM Mitra cake, dimana dalam Rekayasa Perangkat Lunaknya menggunakan bahasa pemrograman PHP, Database management system menggunakan MySql dengan teknik rancangan menggunakan UML dalam bentuk Use Case, Class Diagram, Activity Diagram

Hasil dari penelitian ini menghasilkan aplikasi perhitungan harga pokok produksi yang dapat mengelola pencatatan produksi dalam perhitungan harga pokok produksi, menghasilkan laporan harga pokok produksi, sehingga ketepatan hitungan harga pokok produksi lebih akurat dan menghindari dari kerugian produksi dimasa mendatang.
\end{abstract}

Kata kunci : UMKM, Rekayasa, Harga Pokok Produksi

\section{ABSTRACT}

UMKM Mitra Cake is one of the UMKM engaged in the production of cake food in Bandar Lampung. In the process of calculating the cost of goods manufactured, it is still done manually, so that the accuracy of the calculation is less accurate and results in inaccuracies in the calculation of the remaining business results, therefore Mitra Cake needs an application that is able to calculate and process the right cost of goods manufactured data so that it is not wrong in determining the cost of production.

The purpose of this study is to produce an application for calculating the cost of production at UMKM Mitra cake, where the Software Engineering uses the PHP programming language, the Database management system uses MySql with the design technique using UML in the form of Use Cases, Class Diagrams, Activity Diagrams.

The results of this study produce an application for calculating the cost of production that can manage production records in the calculation of the cost of production, produce a report on the cost of production, so that the accuracy of the calculation of the cost of production is more accurate and avoids future production losses.

Keywords: UMKM, Engineering, Cost of Production

\section{PENDAHULUAN}

Perkembangan teknologi informasi merupakan media yang paling tepat dalam mencapai suatu tujuan perusahaan atau organisasi untuk 
memperoleh informasi yang cepat dan akurat. Penyajian informasi yang cepat dan akurat ini semakin dibutuhkan oleh berbagai pihak, maka diperlukan suatu alat atau media yang dapat menyajikan informasi tersebut yaitu komputer sebagai alat pengolah data.

Komputer sebagai alat dalam pengolahan data membutuhkan pengembangan perangkat lunak. Pengembangan perangkat lunak dalam paradigma rekayasa perangkat lunak menitikberatkan pada kebutuhan pengguna sistem. Rekayasa perangkat lunak merupakan proses kegiatan perangkat lunak itu sendiri guna mengembangkan, memelihara, dan membangun kembali dengan menggunakan prinsip rekayasa untuk menghasilkan perangkat lunak yang dapat bekerja lebih efisien dan efektif untuk pengguna.

Perhitungan harga pokok produksi merupakan salah satu faktor yang tidak dapat ditinggalkan, sebab apabila pimpinan kurang tepat di dalam menentukan harga pokok produksi mengakibatkan harga jual yang sangat tinggi sehingga kemungkinan pesanan akan berkurang. UMKM Mitra Cake merupakan usaha yang bergerak di bidang produksi Kue. Permasalahan yang dihadapi oleh Mitra Cake ini dalam menentukan perhitungan harga pokok produksi masih menggunakan cara yang sederhana mulai dari pencatatan data sampai dengan penyimpanan data masih menggunakan cara yang manual dalam bentuk pembukuan. sehingga ketepatan hitungan yang kurang akurat dan berakibat pada ketidaktepatan dalam perhitungan sisa hasil usaha, oleh karena itu Mitra Cake membutuhkan aplikasi yang mampu menghitung dan mengolah data harga pokok produksi yang tepat sehingga tidak salah dalam penentuan harga pokok produksi

\section{METODE PENELITIAN}

\subsection{Metode Penelitian}

Jenis penelitian yang digunakan adalah deskriptif. Penelitian deskriptif adalah survei, metode survei merupakan penyelidikan yang diadakan untuk memperoleh fakta-fakta dari gejala-gejala yang ada dan mencari keteranganketerangan secara faktual baik tentang institusi sosial, ekonomi, atau politik dari suatu kelompok maupun suatu daerah (Nazir, 2014).

Metode pengembangan perangka lunak dengan menggunakan Extreme Programming (XP).
Extreme Programming (XP) merupakan suatu pendekatan yang paling banyak digunakan untuk pengembangan perangkat lunak cepat.

Landasan penggunakan metode Extreme Programming (XP) karena sifat dari aplikasi yang dikembangkan dengan cepat melalui tahapan- tahapan yang ada meliputi : planning design, coding dan testing.

\subsection{Teknik Pengumpulan Data}

Dalam penelitian ini teknik pengumpulan data menggunakan beberapa metode antara lain adalah :

1. Metode Wawancara

2. Metode Observasi

3. Metode Kepustakaan

\subsection{Rekayasa perangkat lunak}

Rekayasa perangkat lunak merupakan proses kegiatan perangkat lunak itu sendiri guna mengembangkan, memelihara, dan membangun kembali dengan menggunakan prinsip rekayasa untuk menghasilkan perangkat lunak yang dapat bekerja lebih efisien dan efektif untuk pengguna.

Perangkat lunak atau software adalah seuah perintah program dalam sebuah komputer, yang apabila dieksekusi oleh usernya akan memberikan fungsi dan unjuk kerja seperti yang diharapkan oleh usernya. Pernyataan ini menggambarkan bahwa software atau perangkat lunak ini berfungsi untuk memberi perintah komputer, agar komputer dapat berfungsi secara optimal, sesuai dengan kemauan user yang memberikan perintah

Sehingga dapat disimpulkan bahwa rekayasa perangkat lunak adalah proses kegiatan pengembangan perangkat lunak itu sendiri dengan mengunakan perintah program dalam sebuah komputer sehingga perangkat lunak yang dapat bekerja lebih efisien dan efektif untuk pengguna.

\subsection{Akuntansi Biaya}

Akuntansi biaya adalah suatu bidang akuntansi yang diperuntukkan bagi proses pelacakan, pencatatan, dan analisis terhadap biaya-biaya yang berhubungan dengan aktivitas suatu organisasi untuk menghasilkan barang atau jasa 
Akuntansi Biaya merupakan sumber informasi mengenai berbagai macam pendapatan dan biaya yang dapat diakibatkan oleh rangkaian tindakan alternatif.. Objek kegiatan akuntansi biaya adalah biaya. Proses pencatatan, penggolongan, peringkasan dan penyajian, serta penafsiran informasi biaya adalah tergantung untuk siapa proses tersebut ditujukan, yaitu untuk pihak ekstern perusahaan dan pihak intern perusahaan

\subsection{Harga Pokok Produksi}

Harga pokok produksi adalah daftar biaya produksi yang harus dikeluarkan perusahaan pada periode tertentu. Di dalamnya terkait dengan biaya pengadaan bahan baku, alat produksi, bahan pendukung produksi dan lain sebagainya.

Menurut Sumiyati dan Suwartini 2019. Mengemukakan bahwa harga pokok produksi adalah: Harga pokok produksi (HPP) merupakan jumlah biaya produksi yang melekat pada persediaan barang jadi sebelum barang tersebut laku dijual.

Dalam perusahaan manufaktur yang memproduksi barang sangat penting unsur harga pokok produksi.Selain untuk mengontrol sistem produksi dalam suatu produksi juga sangat penting dalam menghitung laba atau rugi perusahaan dalam produksi produk.Harga pokok produksi adalah akumulasi dari biaya yang dikeluarkan perusahaan untuk menghasilkan produk dan kemudian dibebankan pada produk

Menurut Sulistyowati, Farihah, dan Hartadinata, 2020. Mengemukakan bahwa harga pokok produksi adalah: Harga pokok produksi merupakan biayaproduksi yang berasal dari penjumlahan dati tiga komponen biaya, yaitu biaya bahan baku, biaya

tenaga kerja, dan biaya overhead pabrik, Hargapokok produksi merupakan salah satu biaya yang penting untuk dipertimbangkan karena memiliki beberapa manfaat antara lain untukmenetapkan harga jual produk, sebagai alat kontrol biaya produksi secara keseluruhan, menghitung laba rugi perusahaan, dan menentukan harga pokok persediaan produk jadi yang

disajikan dalam neraca
Berdasarkan definisi di atas, dapat disimpulkan bahwa harga pokok produksi adalah biaya langsung maupun biaya tidak langsung yang dikeluarkan untuk memproduksi suatu barang selama periode tertentu

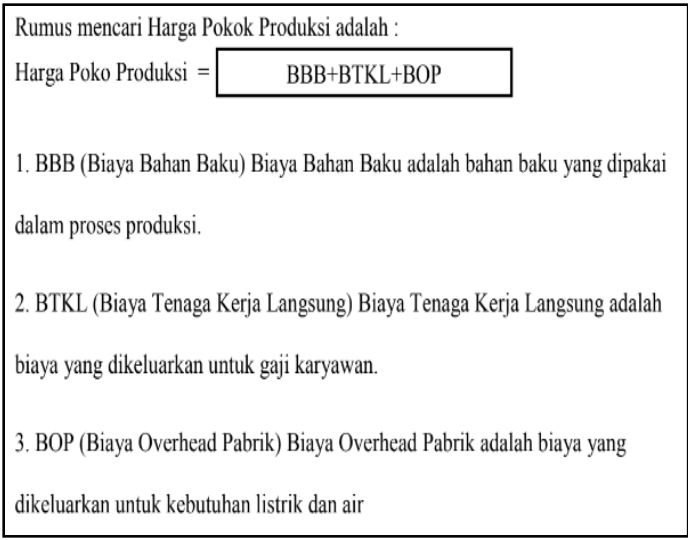

\subsection{Alat Pengembangan Sistem}

Menurut Nugroho (2010) mengemukakan : UML (Unified Modeling Language) adalah sebuah bahasa untuk menentukan, visualisasi, kontruksi, dan mendokumentasikan artifact (bagian dari informasi yang digunakan atau dihasilkan dalam suatu proses pembuatan perangkat lunak. Artifact dapat berupa model, deskripsi atau perangkat lunak) dari sistem perangkat lunak, seperti pada pemodelan bisnis dan sistem non perangkat lunak lainnya.

UML merupakan bahasa standar untuk penulisan blueprint software yang digunakan untuk visualisasi, spesifikasi, pembentukan dan pendokumentasian alat-alat dari sistem perangkat lunak.

\subsubsection{Use Case Diagram}

Menurut Rosa dan Shalahuddin, (2014) mengemukakan :

Use Case Diargam merupakan pemodelan untuk melakukan (behavior) sistem informai yang akan dibuat. Use case digunakan untuk mengetahui fungsi apa saja yang ada di dalam sebuah sistem informasi dan siapa saja yang berhak menggunakan fungsi-fungsi itu. Berikut adalah simbol-simbol yang ada pada diagram use case.

Tabel 1. Simbol Use Case

\begin{tabular}{|l|l|l|l|}
\hline No & Notasi & Keterangan & Simbol \\
\hline
\end{tabular}




\begin{tabular}{|c|c|c|c|}
\hline 1 & Actor & $\begin{array}{l}\text { Pengguna sistem } \\
\text { atau yang } \\
\text { berinteraksi } \\
\text { langsung dengan } \\
\text { sistem }\end{array}$ & \\
\hline 2 & $\begin{array}{l}\text { Use } \\
\text { Case }\end{array}$ & $\begin{array}{l}\text { Lingkaran elips } \\
\text { dengan nama } u s e \\
\text { case nya tertulis } \\
\text { ditengah lingkaran }\end{array}$ & e Case \\
\hline 3 & $\begin{array}{l}\text { Assocat } \\
\text { ion }\end{array}$ & $\begin{array}{l}\text { Garis yang } \\
\text { berfungsi } \\
\text { menghubungkan } \\
\text { actor dengan use } \\
\text { case. }\end{array}$ & \\
\hline 4 & Relasi & $\begin{array}{l}\text { Sebagai } \\
\text { penghubung } \\
\text { antara actor } \\
\text { usecase, use case- } \\
\text { usecase dll }\end{array}$ & \\
\hline 5 & $\begin{array}{l}\text { Include } \\
\text { Relatio } \\
\text { nship }\end{array}$ & $\begin{array}{l}\text { Memungkinkan } \\
\text { suatu usecase } \\
\text { untuk } \\
\text { menggunakan } \\
\text { fungsionalitas } \\
\text { yang disediakan } \\
\text { oleh usecase yang } \\
\text { lainnya. }\end{array}$ & 《include $\gg>$ \\
\hline 6 & $\begin{array}{l}\text { Extend } \\
\text { Relatio } \\
\text { nship }\end{array}$ & $\begin{array}{l}\text { Memungkinkan } \\
\text { usecase memiliki } \\
\text { kemungkinan } \\
\text { untuk memperluas } \\
\text { fungsionalitas } \\
\text { yang disediakan } \\
\text { oleh usecase yang } \\
\text { lainnya. }\end{array}$ & te \\
\hline
\end{tabular}

\subsubsection{Activity Diagram}

Menurut Rosa dan Shalahuddin, (2014) mengemukakan : Activity Diagram menggambarkan workflow (aliran kerja) atau aktivitas dari sebuah sistem atau proses bisnis atau menu yang ada pada perangkat lunak. Perlu diperhatikan bahwa diagram aktivitas menggambarkan aktivitas sistem bukan apa yang dilakukan aktor, jadi aktivitas yang dapat dilakukan oleh sistem. Berikut adalah simbolsimbol yang ada pada diagram aktivitas.

Tabel 2. Simbol Activity Diagram

\begin{tabular}{|l|l|l|l|}
\hline No. & Notasi & Keterangan & Simbol \\
\hline 1 & $\begin{array}{l}\text { Initial } \\
\text { State }\end{array}$ & $\begin{array}{l}\text { Titik awal } \\
\text { untuk } \\
\text { memulai } \\
\text { suatu }\end{array}$ & \\
\hline
\end{tabular}

\begin{tabular}{|c|c|c|c|}
\hline & & aktivitas & \\
\hline 2 & $\begin{array}{l}\text { Final } \\
\text { State }\end{array}$ & $\begin{array}{l}\text { Titik akhir } \\
\text { untuk } \\
\text { mengakhiri } \\
\text { suatu } \\
\text { aktivitas }\end{array}$ & \\
\hline 3 & Activity & $\begin{array}{l}\text { Menandaka } \\
\text { n sebuah } \\
\text { aktivitas }\end{array}$ & \\
\hline 4 & $\begin{array}{r}\text { DeciSis } \\
\text { te } \\
\text { Mon }\end{array}$ & $\begin{array}{l}\text { Pilihan } \\
\text { untuk } \\
\text { pengambila } \\
\text { n keputusan }\end{array}$ & \\
\hline 5 & $\begin{array}{c}\text { Control } \\
\text { Flow }\end{array}$ & $\begin{array}{l}\text { Arus } \\
\text { aktivitas }\end{array}$ & \\
\hline 6 & $\begin{array}{c}\text { ForkJoi } \\
n\end{array}$ & $\begin{array}{l}\text { Menunjukka } \\
\text { n kegiatan } \\
\text { menggabun } \\
\text { gkan dua } \\
\text { panel } \\
\text { activity } \\
\text { menjadi satu } \\
\text { atau satu } \\
\text { panel } \\
\text { activity } \\
\text { menjadi dua }\end{array}$ & \\
\hline \multirow{2}{*}{8} & \multirow{2}{*}{ Note } & \multirow{2}{*}{$\begin{array}{l}\text { Tanda } \\
\text { penerimaan }\end{array}$} & $\frac{\downarrow}{<\text { no receive action> }}$ \\
\hline & & & $\downarrow$ \\
\hline 9 & & $\begin{array}{l}\text { Catatan } \\
\text { khusus untuk } \\
\text { sebuah } \\
\text { aktivitas }\end{array}$ & \\
\hline
\end{tabular}

\subsubsection{Class Diagram}

Menurut Rosa dan Shalahuddin (2013) mengemukakan :

Class Diagram menggambarkan struktur sistem dari segi pendefinisian kelas-kelas yang akan dibuat untuk membangun sistem. Kelas memiliki apa yang disebut atribut dan metode atau operasi. Berikut adalah simbol-simbol yang ada pada diagram Kelas. 
Tabel 3. Simbol Class Diagram

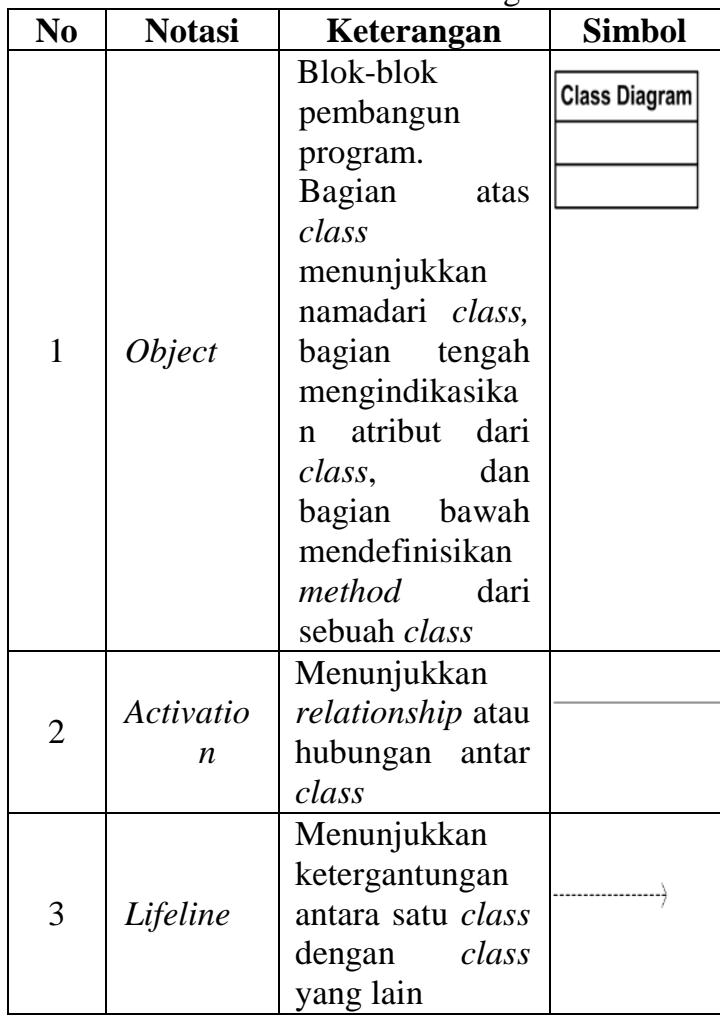

\subsection{Aplikasi yang digunakan}

\subsubsection{Notepad++}

Notepad++ adalah suatu text editor yang berjalan pada Operating System(OS)Windows. Notepad++disini menggunakan komponenkomponen Scintilla agardapat menampilkan dan menyunting text dan berkas source code berbagai bahasa pemrograman, Notepad++ didistribusikan sebagai Free Software (gratis)Proyek ini dilayani oleh Sourceforge.net dengan telah diundub lebih dari 27 jutakali dan dua kali memenangkan penghargaan SourceForge Community ChoiceAward for Best Developer Tool."

\subsubsection{PHP}

PHP: Hypertext Preprocessor, atau PHPmerupakan open-source,merupakan bahasa pemrograman yang bersifat serverside. PHP dirancangKhusus untuk mengisi kesenjangan antara halaman HTML. statis danhalaman penuh dinamis, seperti yang dihasilkan melalui kode CGI. PHPtertanam langsung dalam kode sumber XHTML; kita akan menerapkansintaks standar W3C dan struktur untuk dokumen XHTML danmengintegrasikan CSS untuk memformat dokumen untuk tampilanbrowser."

PHP merupakan program Server Slide Scripting yaitu program yang dapat dikompilasi atau diterjemahkan ke dalam server, sehingga dapat menghasilkan aplikasi web dinamis. PHP juga dapat dikoneksikan dengan berbagai macam database seperti MYSQL". Dari pendapat di atas dapat disimpulkan bahwa PHP adalah penerjemahanbaris kode yang bisa dibaca atau dimengerti oleh komputer karena PHP bisadiletakkan pada script HTML atau sebaliknya. PHP dikhususkan ntukpengembangan web dinamis.

\subsubsection{XАMPP}

XAMPP adalah sebuah aplikasi open source terkait pengelolaan server yang dikembangkan oleh Apache Friends. Karena bersifat open source, aplikasi ini bisa digunakan secara gratis. Selain itu, sesuai namanya, X pada XAMPP berarti cross plarform. Artinya, mendukung berbagai platform seperti Windows, macOS dan Linux.XAMPP sendiri terdiri dari Apache,MariaDB (yang dikembangkan dari MySQL), PHP dan Perl.XAMPP juga memberikan solusi sederhana dan cukup ringan dijalankan, memungkinkan membuat web server lokal untuk melakukan pengetesan website, XAMPP dapat dijalankan pada Mac dan Linux.

Berdasarkan pengertian diatas dapat disimpulkan bahwa Xampp merupakan tool pembantu pengembangan paket perangkat lunak berbasis open source yang menggabungkan Apache web server, MySQL, PHP dan beberapa modul lainnya di dalam satu paket aplikasi.

\subsubsection{MySQL}

MySQL adalah DBMS yang open source dengan dua bentuk lisensi,yaitu Free Software (perangkat lunak bebas) dan Shareware (perangkat lunak berpemilik yang penggunaannya terbatas). Jadi MySQL adalah database server yang gratis dengan lisensi GNU General Public License(GPL) sehingga dapat Anda pakai untuk keperluan pribadi atau komersialtanpa harus membayar lisensi yang ada."

\section{HASIL DAN PEMBAHASAN}

\subsection{Hasil Penelitian}




\subsubsection{Analisa Kebutuhan Sistem}

Pada proses pengolahan data penentuan produksi yang dilakukan UMKM Mitra Cake saat ini, pencatatan data dilakukan masih dalam bentuk pembukuan dan proses perhitungan yang dilakukan masih mengkalkulasi seluruh biaya bahan baku yang dikeluarkan untuk menyelesaikan satu pesanan. untuk mengatasi permasalahan tersebut maka dibutuhkan aplikasi yang mampu menghitung harga

pokok produksi secara tepat dengan menggunakan metode full costing untuk menentukan harga pokok produksi berdasarkan pesanan yang diterima.

\subsubsection{Analisa Kebutuhan Fungsional}

Analisa kebutuhan fungsional dilakukan untuk mengetahui alur informasi yang berlaku pada sistem tersebut sehingga didapatkan pemahaman akan kerja dari sistem. Analisis kebutuhan fungsional pada sistem ini adalah:

1. Admin dapat melakukan input bahan baku, tenaga kerja, biaya overheadpabrik, dan Mencetak Laporan.

2. Admin dapat menampilkan, menambah, menghapus, mengedit serta menyimpan data yang telah diinput

\subsection{Perancangan Sistem}

\subsubsection{Use Case Diagram}

Use case diagram yaitu salah satu jenis diagram pada UML yang menggambarkan interaksi antara sistem dan aktor, use case diagram juga dapat men-deskripsikan tipe interaksi antara si pemakai sistem dengan sistemnya

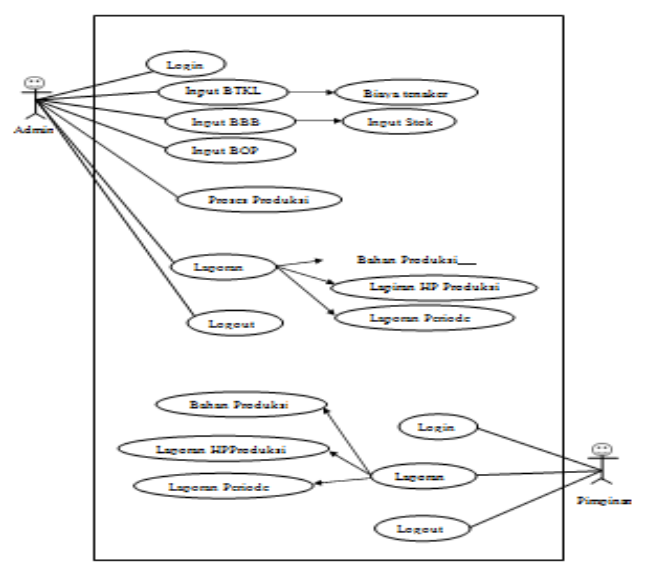

Gambar 1. Use Case Diagram

\subsubsection{Class Diagram}

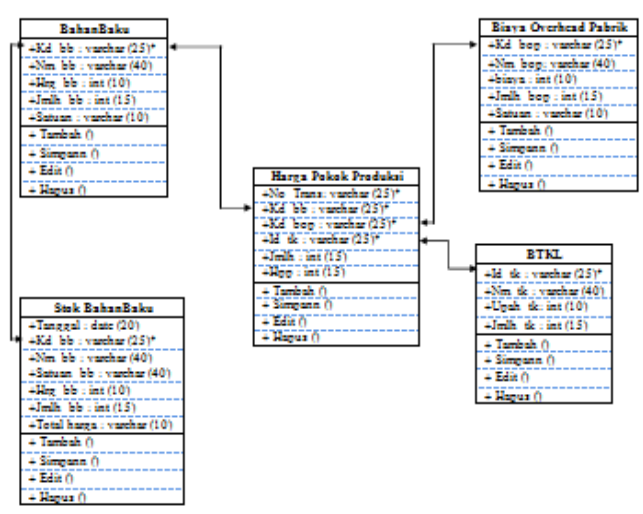

Gambar 2. Class Diagram

\subsubsection{Activity Diagram}

Activity Diagram ini menggambarkan rangkaian aliran dari aktivitas, digunakan untuk mendeskripsikan aktivitas yang dibentuk dalam suatu operasi sehingga dapat juga digunakan untuk aktivitas lainnya seperti use case atau interaksi. Activity diagram dapat dilihat pada gambar di bawah ini:

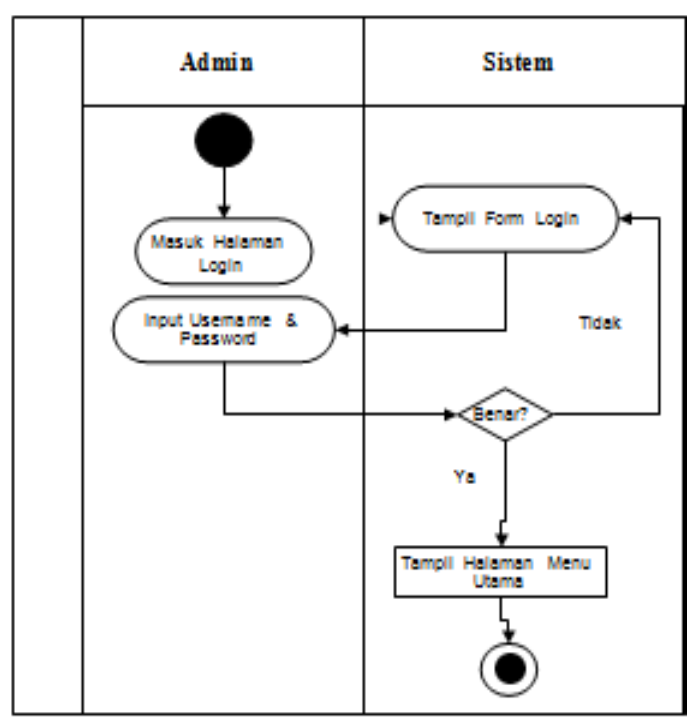

Gambar 3. Activity Diagram Login 


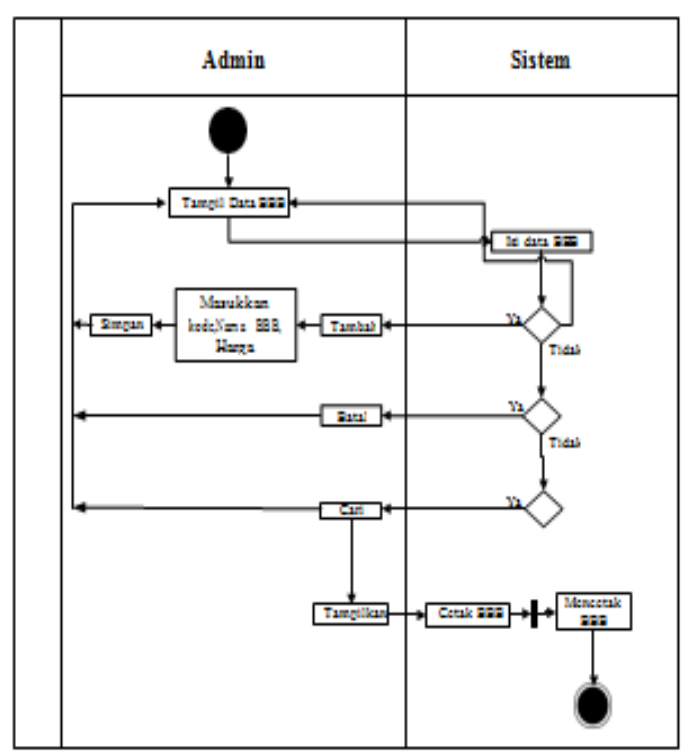

Gambar 4. Activity Diagram Biaya Bahan Baku

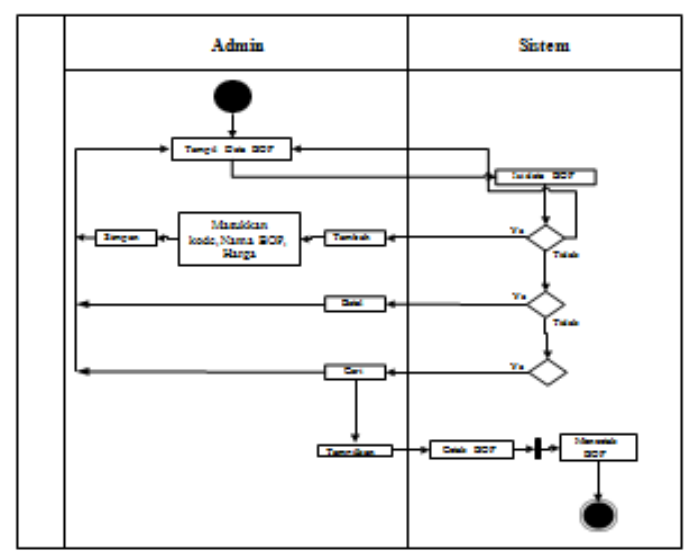

Gambar 5. Activity Diagram BTKL

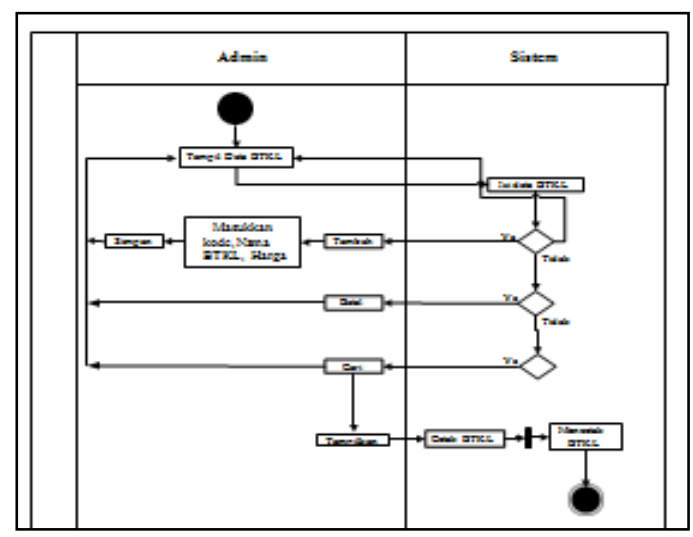

Gambar 6. Activity Diagram BOP

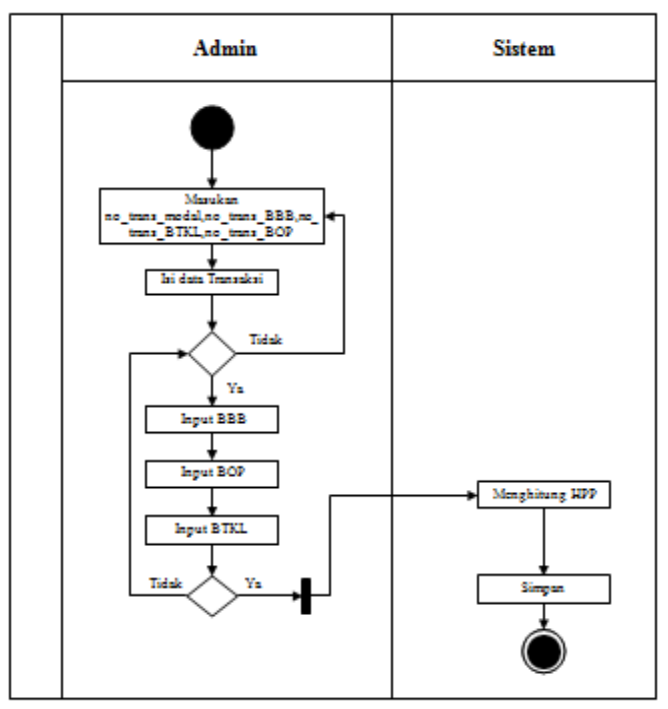

Gambar 7. Activity Diagram HPP

\subsubsection{Rancangan Tampilan Form Login}

Tampilan halaman login adalah tampilan halaman yang berfungsi untuk memeberikan hak akses untuk msuk ke dalam sistem. Tampilan halaman login dapat dilihat pada gambar

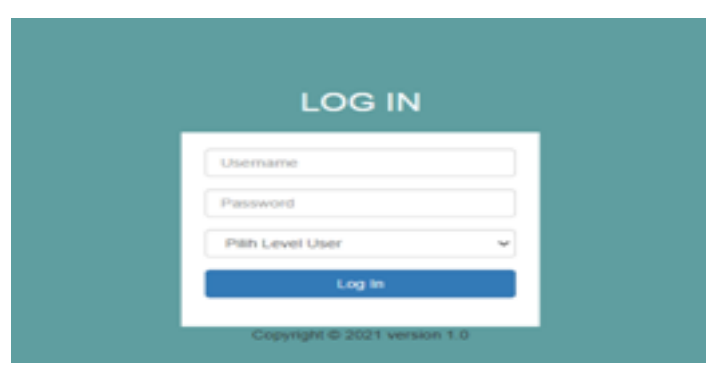

Gambar 8. Rancangan Tampilan Form Login

\subsubsection{Rancangan Tampilan Menu Utama}

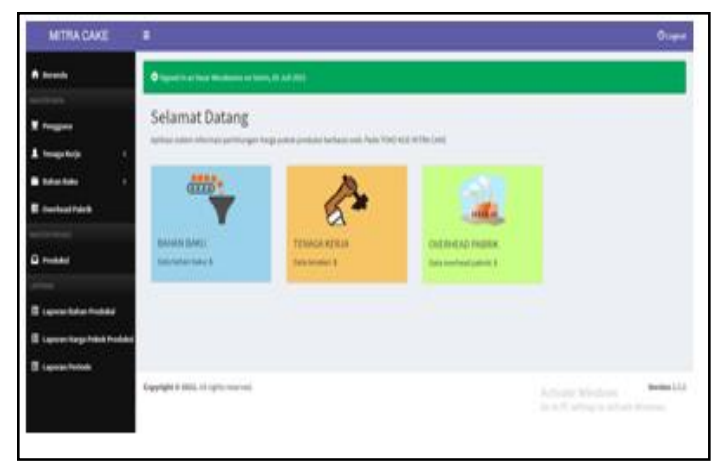

Gambar 9. Rancangan Tampilan Menu Utama 


\subsubsection{Rancangan Tampilan Biaya Bahan Baku}

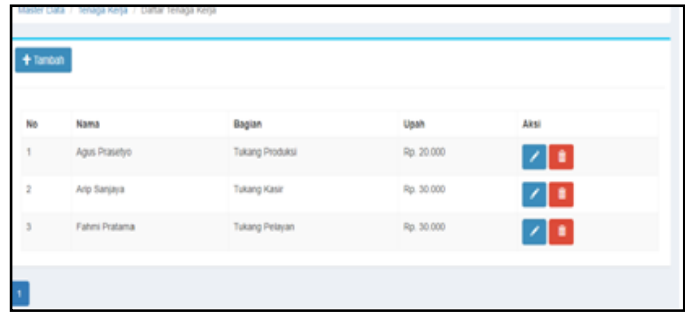

Gambar 10. Rancangan Tampilan Biaya Bahan Baku

\subsubsection{Rancangan Tampilan Biaya Tenaga Kerja}

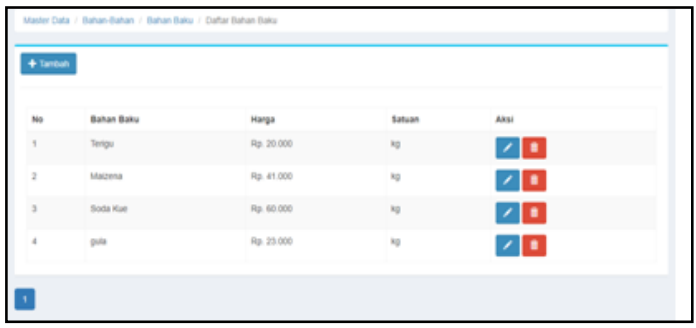

Gambar 11. Rancangan Tampilan BTKL

\subsubsection{Rancangan Tampilan BOP}

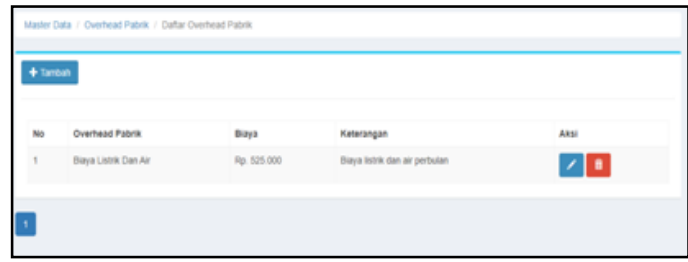

Gambar 12. Rancangan Tampilan Data BOP

\subsubsection{Rancangan Tampilan Data HPP}

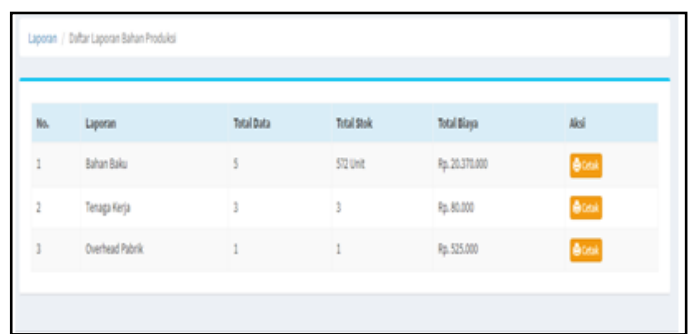

Gambar 13. Rancangan Tampilan Data HPP

\subsection{PEMBAHASAN}

Program aplikasi yang dikembangkan mampu menghasilkan informasi Perhitungan Harga Pokok Produksi secara akurat. Dengan adanya Laporan Perhitungan Harga Pokok Produksi dalam aplikasi ini maka mengetahui Jumlah Harga Pokok Produksi per unit yang ada.

Program aplikasi Perhitungan Harga Pokok Produksi mampu mempermudah dalam pengolahan data. Dimana aplikasi ini tidak melakukan penginputan data Daftar Bahan Baku, Daftar Barang Produksi dan Daftar Biaya sehingga tidak secara berulang melainkan mengambil data yang sudah ada dan yang sudah tersimpan kedalam database, sehingga dapat mempermudah pengguna dalam penginputan data dan dapat meminimalisir kesalahan dalam pengolahan data Perhitungan Harga Pokok Produksi.

Program Aplikasi Perhitungan Harga Pokok Produksi yang di kembangkan mampu membuat dan menyajikan laporan secara akurat dan tepat waktu, baik laporan Perhitungan Harga Pokok Produksi. Sehingga dengan adanya sistem Perhitungan Harga Pokok Produksi ini akan menimbulkan efisiensi waktu. Laporan yang dibuat juga dapat dipertanggung jawabkan kebenarannya dikarenakan seluruh isi laporan Perhitungan Harga Pokok Produksi berdasarkan transaksi yang dilakukan selama periode tersebut.

\section{PENUTUP}

Berdasarkan rumusan masalah, hasil penelitian dan pembahasan maka dapat disimpulkan sebagai berikut :

1. Memudahkan admin dan pemilik untuk mendapatkan mengetahui informasi mengenai harga pokok produksi dengan akurat, tepat waktu, dan relevan.

2. Menghasilkan pembangunan Sistem Informasi Akuntansi Untuk Perhitungan Harga Pokok Produksi pada UMKM Mitra Cake di Bandar Lampung.

3. Dengan menggunakan UML mengakomodasi perubahan kebutuhan perangkat lunak dapat teratasi dan kesalahan yang terjadi seperti error atau bug dapat ditemukan dan diperbaiki selama tahapan pengembangan.

4. Dengan adanya sistem yang baru, maka 
dapat mempercepat proses perhitungan harga pokok Produksi.

\section{DAFTAR PUSTAKA}

[1] Arief, M.Rudianto, 2011, Pemrograman Web Dinamis Menggunakan Php dan Mysql, ANDI : Yogyakarta.

[2] A. S., Rosa dan Shalahuddin, M. 2013, Rekayasa Perangkat Lunak Terstruktur Dan Berorientasi Objek. Informatika. Bandung.

[3] Adi Nugroho, 2010, Rekayasa Perangkat Lunak Berbasis Objek dengan Metode USDP. Andi.Yogyakarta

[4] Moh. Nazir, 2014. Metodologi Penelitian, Ghalia Indonesia, Bogor

[5] Rossa, \& Shalahuddi, 2011, Rekayasa Perangkat Lunak Terstruktur dan Berorientasi Objek, Informatika Bandung, Bandung.

[6] Rosa dan Shalahuddin, 2014, Rekayasa Perangkat Lunak Struktur dan Berorientasi Objek. Bandung : Informatika.

[7] Sumiyati dan Suwartini.2019.Produk Kreatif dan Kewirausahaan Akuntansi dan Keuangan Lembaga.PT Gramedia Widiasarana Indonesia.Jakarta 